\title{
Constitutional Amendment and Concept of Constitution
}

\author{
Prof. Dr. Benito Aláez Corral
}

University of Oviedo (Spain)

benito@uniovi.es

\begin{abstract}
Constitutional amendment raises a number of complex legal issues related to how it can legally help to protect constitutional democracy. Those issues will receive a different answer depending on the concept of the Constitution you depart from. This article will analyze the implications for constitutional amendment of a formal and a material concept of the Constitution, out of the many concepts of the Constitution that are available. After a critical analysis of both concepts, an alternative formal-functional approach will be proposed. This last concept of the Constitution will be conceived as the better way of assessing in modern fully differentiated legal systems the theoretical implications of constitutional amendment, regarding the legally non-existing difference between constituent power and amending power, the contingency of the substantial limitations upon the amending power, the derogatory consequences of constitutional polymorphism, as well as the need of an only ex ante, but not ex post, judicial review of the constitutional amending procedure.
\end{abstract}

Keywords: constitutional theory, constitutional amendment, eternity clauses, judicial review, constitutional entrenchment

Reference to this paper should be made as follows: ALAEZCORRAL, B., 'Constitutional Amendment and Concept of Constitution', International Journal of Human Rights and Constitutional Studies, Vol. 7, No. 2, 2020

Biographical notes: Full Professor at the University of Oviedo (Spain)

This article is a revised and shortened version of a paper entitled "(title in Spanish of your respective papers)" presented at the conference "Reforma constitucional y defensa de la democracia" celebrated in Oviedo from 26th to 31 st of May 2019 and published in Spanish in the Book "Reforma constitucional $y$ defensa de la democracia" by the Centro de Estudios Políticos y Constitucionales", all of which has been possible thanks to the research grant of the Spanish Ministry of Economy and Competitiveness MINECO-18-DER201782196- $P$.

\section{Theoretical issues involved with constitutional amendment}

Constitutional amendment raises a number of complex legal issues. For instance, it is necessary to determine whether the constituent power and the amending power are legally 


\section{B. Alaez Corral}

equivalent, whether People's constituent power can change the Constitution outside the constitutionally provided amending procedure, whether through the constitutional amending procedure it is possible not only to make changes in the Constitution but also to replace or substitute it, and, related to that, whether there are substantial limitations upon constitutional amendment, either expressly established eternity clauses or implicit limitations. The legal role of constitutional entrenchment must also be determined, as well as whether a judicial review of constitutional amendments is compatible with a constitutional democracy or not. Each of these issues is related to how constitutional amendment can legally help to protect constitutional democracy, and will receive a different answer depending on the concept of the Constitution you depart from (Ehmke, 1953, 85). This dependence has to do with the fact that constitutional interpretation, unlike interpretation of ordinary legislation, requires, before applying the traditional methods of legal interpretation (historical, textual, structural, sociological, teleological), a theoretical elaboration of the legal weight and binding effect of the Constitution taking into account for this purpose the provisions of each constitutional text (Böckenförde 1991, 83-84).

Carrying out a taxonomy of the Constitution's concepts is complex and can follow very different criteria and epistemological perspectives, not all of them strictly legal, such as, for instance, a rational-normative/historical/sociological Constitution, a normative/nominal/semantic Constitution, etc... We do not consider this taxonomy of concepts of the Constitution useful for the legal analysis of constitutional amendment and its relationship to the protection of constitutional democracy, because it mixes political philosophy and political sociology with legal analysis in defining each of the terms of the classifications. We consider, instead, the conceptual dichotomy between a formal and a material concept of the Constitution much more adequate. This dichotomy is not about philosophically contrasting form and substance, as it was done in ancient times. The difference between both concepts of the Constitution -and therefore of the concept of democracy when the Constitution is a democratic one- relies on the different methodological way of defining what is a Constitution and has a decisive impact on the opposing answers given to the issues raised by the constitutional amendment (Aláez Corral, $2000,3)$. On the one side, a material concept takes into account a meta-positive external substance, outside and over the constitutional positive law, which defines what "ought to be" a Constitution as a legal norm; whereas, on the other side, a formal concept takes into account, in defining what a Constitution is, only the formal outlook of certain legal rules 


\section{Constitutional Amendment and Concept of Constitution}

(the constitutional) of positive law as well as the internal function of this formalization for the rest of the legal system.

Indeed, constitutional substance, as an idea related to the founding and organizing of political power, was not itself something new when the first modern constitutional documents appeared by the end of the 18th century. Prior to that moment, the role played by this constitutional substance establishing political power and founding the positive law -the exclusive result of the human will (Austin, 1970,11)- was already played by natural law, that is, a meta-positive law. What was then new was that this meta-positive substance adopted the form of a new and specific type of positive law, the Constitution, conceived as supreme law of the land instead of natural law (Corwin, 1929, 365). This represented a decisive evolutionary step in the differentiation of (positive) law from other social subsystems such as Politics or Morals (Luhmann, 1995, 112-113), which however did not develop homogeneously in all historical times nor all over the world.

Hence the formulation of a concept of the Constitution presupposes a methodological option. Either the Constitution is conceptualized as a norm of positive law regardless of its political function and values, or it is conceptualized as a normative political structure/value recovered by some norms of positive law, but different to and binding for them. Neither the Constitutions of classical Greece or Rome nor the medieval Constitutions, and not even the first Enlightened Constitutions, were already conceived as pure legal instruments differentiated from political structures/values. Our conceptual analysis must therefore focus on contemporary western constitutional documents -from the 20th century onward-, when at least there was a methodological reflection on whether Law and Politics/Morals should and could be conceived as differentiated social communication spheres. Only under this premise is the dichotomy between the material and formal concepts of the Constitution useful for the theoretical analysis of constitutional amendment. Although these two types of concept of the Constitution may appear in different theoretical ways, our analysis will take into account only the common characteristics of each one that are defining for their formal or material conceptualization and for the understanding of constitutional amendment.

The case of India is a good example of the effects this typology of concept of the Constitution may have for answering the aforementioned constitutional amendment issues. 


\section{B. Alaez Corral}

Responding to the Supreme Court of India of 1973 (Case of Kesavananda Bharati v. State Of Kerala, 4 SCC 225) that stated its power to review constitutional amendments violating the "basic structure" underlying the text of the Indian Constitution, the Parliament of India, in the exercise of its amending power, expressly introduced in 1976 two new paragraphs, $4^{\text {th }}$ and $5^{\text {th }}$, in art. 368 . Those paragraphs expressly prohibited the judicial review of approved constitutional amendments, and denied the existence of any substantial limitations upon the amending power -which is considered by the Constitution itself "a constituent power". However, the Supreme Court of India, four years later, in its decision of July 31st 1980 (Case of Minerva Mills Ltd. and Others v. Union of India and Others, 3 SCC 625) declared both paragraphs unconstitutional, precisely for infringing again the "basic structure" doctrine, considered an implicit limitation upon the amending power. According to the theoretical premises we will develop next, a formal concept of the Constitution would lead to say that the constitutional amending power of India is, as stated in art. 368.5, the constituent (legalized) power, that it is not substantially limited and that no Court -constituted power- is allowed by the constitutional text to review the constitutional amendments -the work of constituent power-, wherefore the two mentioned decisions of the Supreme Court of India, as a consequence of that, are unconstitutional and undemocratic. On the contrary, a material concept of the Constitution would lead to confirm the decisions of the Supreme Court of India, and therefore that the constitutional text is not the "true" Constitution -nor its democracy the "true" democracy to be protected. The true Constitution would be identified with the not necessarily positivized underlying basic structures that, placed over the constitutional text, confer the Supreme Court a nonderogable power to review constitutional amendments -the work of a constituted powerwhich are subject to the implicit limitations deriving from the basic structure, being art. 368.4 and 5 of the Indian Constitution unconstitutional constitutional norms.

\section{Constitutional amendment under a material concept of the Constitution}

1. Constitutional substance and the prescription of a supra-positive Constitutional essence 


\section{Constitutional Amendment and Concept of Constitution}

The material concept of the Constitution does not define it on the basis of positive constitutional law, but of a meta-positive constitutional substance of political and moral nature that links the "ought" of the positive law with the "be" of political reality. In a simplistic way, we might say that a material concept prescribes what the Constitution should politically and legally be, and does not describe its distinct legal-positive form. It doesn't matter at all whether this constitutional substance derives from natural law, from political practice or from intrinsic or extrinsic morality. In any case we are talking about something meta-positive that normatively decides the scope of action of positive constitutional law.

The Constitution, thus, is a norm that regulates certain essential aspects of a political community, becoming its supportive structure as a fundamental political decision (Schmitt, 1989, 22), as an integrating reality (Smend, 1968, 189), or as an instrument sustaining the social institution of the State (Mortati, 1940, 65-67). If we update this material concept in the light of the political philosophy of constitutionalism, widely accepted in Western democracies since the 18th century (Ackerman, 1997, 771), the Constitution would be defined in the same way as Article XVI of the Declaration of Rights of Man and Citizen of 1789: "A society in which the guarantee of rights is not established, nor determined the separation of powers, lacks of Constitution", including the attribution of sovereignty, and therefore of constituent power, to the People.

Hence, a characteristic of the material concept of the Constitution is that it introduces in its definition -and this has decisive implications for constitutional amendment- a constitutional substance belonging to the sphere of the political "be", or to the moral meta-positive "ought". This factual or meta-positive essence of the Constitution conditions the validity (constitutionality) of positive constitutional law and explains why we can talk about unconstitutional constitutional law (Bachof, 1979, 17). The affirmation of a true Constitution, endowed with supremacy, is therefore linked to its correspondence to a presupposed political content as an achievement of humanity, expressed by the constituent power of the People and not bound to any legal form of positive law, turning the concept of the Constitution into a normative and not a descriptive one.

\section{Implications of the material concept of the Constitution for constitutional amendment}




\section{B. Alaez Corral}

As already mentioned, the material concept of the Constitution attaches the constituent (original) power to the sovereign People. However, contrary to what is often thought, the People's constituent power is not conceived a mere fact, but as a legal power, subject to a higher law, that empowers it to create the positive constitutional text. This idea has a first transcendental implication for constitutional amendment: constitutional power and constitutional amendment power are not the same, nor can they be the same, under no circumstances, since the latter is always subordinated to the former, from which the amending power is a mere delegation. Hence, the constitutional amending power is considered, by its very nature, as not only formally but also materially limited, since it cannot surpass the limits of the power delegated by the constituent power to maintain, update and improve the Constitution by making changes in the constitutional text, but not by changing the Constitution.

From that it also follows that the constituent power can always change or replace the Constitution, even acting outside the constitutionally established amending procedure, either in the form of a Constitutional Convention, a Constituent Assembly or through a People's referendum. Of course this presupposes understanding constitutional change in terms of (political) regimes, orders, and institutions and not only in terms of positive law (Griffin, 2007, 57). Some constitutional texts, such as art. 146 of the German Constitution, reflect this possibility of intervention of the constituent power outside the constitutional amendment procedure of art. 79 and, without such textual allusion, part of the American doctrine affirms the existence of a "higher law making", which would allow the People of the United States to modify the Constitution regardless of the procedure provided for in art. V of the Constitution (Ackerman, 1991, 266). However, the material concept of the Constitution does not conceive of the original constituent power as a mere factual power, but envisages it as a legal power -a constituent authority (Kay, 2011, 727)- that, although not subject to positive law, is bound by internal and external supra-positive law regarding its competence to create, replace or substitute a Constitution institutionalizing constitutionalism (Bernal Pulido, 2018, 82). This supra-positive law predetermines a number of aspects; from the competence of the Constitutional Convention/Assembly and/or electoral body to elaborate, replace or substitute the Constitution, up to the material limitations this constituent power is subject to (Böckenförde, 2017, 182-183).

Turning back now to the constitutional amending power, the material concept of the Constitution considers intangibility clauses a necessary content of the constitutional 


\section{Constitutional Amendment and Concept of Constitution}

text, and when not expressly included, these clauses must be implicitly presupposed in order to guarantee the essence of the Constitution (Nef, 1942, 128). "Constitutional legitimacy" thus becomes the source of these expressed or implied substantial limitations upon constitutional amending power, as long as it is characteristic to it to exist and bind regardless of the constitutional text (Hauriou, 1923, 296-297), in other words, regardless positive constitutional law. The constitutional amendment procedure, which allows the adaptation of the constitutional text to social changes, ultimately serves to protect the Constitution's essence. It does not serve to the positivity (change) of law as an end in itself, but only as a means to protect the above-mentioned supra-positive law. Consequently, constitutional legitimacy turns constitutional amendments that seek to suppress democracy by democratic means into a logically impossible paradox. And if this happens, it only can be considered, legally speaking, a constitutional fraud inasmuch as they do not respect the moral-political values underlying the exercise of the constitutional amending power and the source of validity of its competence (Liet-Veux, 1943, 143-145).

Finally, the constitutionality review of the constitutional amendments is for this material concept an inherent and necessary tool for the safeguarding of the Constitution, that is, of the inalienable values of constitutionalism (Roznai 2017, 180). Following this idea, some Supreme or Constitutional Courts, when not always expressly empowered by positive law, have themselves self-empowered to review, and if necessary to invalidate, constitutional amendments that undermine the basic structure of the Constitution (Decisions of the Supreme Court of India Kesavananda Bharati v. State Of Kerala, 4 SCC 225, and Minerva Mills Ltd. v. Union of India, 3 SCC 625), the constitutional architecture (Canada Supreme Court Decisions Reference re Senate amendment (2014 SCC 32) and Reference re Supreme Court Act, ss. 5 and 6, 2014 SCC 21), the fundamental principles or the intangible supra-positive core of the Constitution (BVerfGE 1,14,18) or the implicit substantive core of the Constitution (Decision of the Slovak Constitutional Court of $30^{\text {th }}$ January 2019, PL. Ú 21/2014-96).

\section{Short discussion of the material concept of the Constitution}

Contemporary material concepts of the Constitution pose some important theoretical challenges. In the first place, its base is purely ideological. The normative attribution of the original constituent power to the People is, legally speaking, nothing but 


\section{B. Alaez Corral}

a fallacy, which can only pretend to fulfill a symbolic function for the democratic legitimacy of the legal system, but which cannot be based on the law, be positive or suprapositive, without contradicting its very foundational premise: People's sovereignty. Who are the People? Who creates the People and defines its membership? Who empowers the People and attributes the constituent power to it? These are questions for which there is no legal answer without denying People's sovereignty, and for which a democratic answer is not possible (Offe, 1998, 115-118). Secessionist conflicts illustrate this, like no other: if the sovereign People is not the mere aggregation of individuals resident in a given space and time, but requires a certain shared political awareness (Grimm, 1995, 295-296), it is because the differences between the majority and the minorities have been reduced to a unity. However this is done, it is possible because either positive or supra-positive law has previously decided who can and who cannot express a will of shared political consciousness -in other words, the personal and spatial scope of the demos, as well as the procedure for the expression of its unitary will, which is precisely what is contended by the minority in secessionist conflicts.

Secondly, if the constituent power is conceived as a power limited not by positive constitutional law but by supra-positive law, even though that is often omitted in the reasoning (e.g. Roznai, 2017, 108-110), then in purity constituent power is not an original power, but a derivative one, ultimately depriving of sense to its conceptual differentiation from the constitutional amending power. Indeed, only by appealing to any kind of "natural law" empowering the constituent power to draft a Constitution under the terms of constitutionalism could it be asserted that the People have a "right" (legally and not only morally speaking) to convene a constitutional convention/assembly or a referendum in order to replace the current Constitution or approve ex nihilo a new one. And also that such right of the People does not allow it to destroy itself nor to destroy democracy, as it is conceptually limited by its service to the values of constitutionalism (Bernal Pulido, 2018, 74).

Finally, the concretion of the Constitution's essence that cannot be amended is not a peaceful task in constitutional democracies (Schwarzberg, 2007, 197), especially because it implies getting down from the abstract sky of political and moral values to detailed constitutional contents and this has to be done ultimately regardless of the constitutional text. Think, for instance, that the above-mentioned impossibility to democratically define the personal and spatial scope of the sovereign People spreads to 


\section{Constitutional Amendment and Concept of Constitution}

other concretions such as whether the sovereign People is built on the basis of a national identity or of the subjection of individuals to the law; who has the power to define this supra-positive constitutional essence, especially if this power is attached to the Courts whose determination and competences are ultimately established by positive law; or what are the democracy elements belonging to this Constitution's essence and whether it is democratic to eliminate democracy by democratic means. The concretion of those issues either via positive or supra-positive law contends People's sovereignty and depends, ultimately, on the acceptance/denial of the methodological premise that positive law -at least in the Western world- has reached a degree of functional differentiation that allows it, through positivity to program in a self-referring way from within the code difference law/outlaw. And all this is observable from the outside, on a second level, by the legal science (Luhmann, 1993, 496- 497).

\section{Constitutional amendment under a formal concept of the Constitution}

\section{Constitution formalization and the return to positive law description}

The formal concept of the Constitution, unlike the material concept, defines the Constitution from within the positive law through its legal form, not through its metapositive content. Formalization means, in a broad sense, the juridification of a concept that traditionally was defined as a political category. In a stricter sense, the term implies additionally the concrete legal method of understanding the Constitution as a positive legal norm that is not defined by its content but only by the legal form it adopts, though traditionally it deals with the regulation of norm production by the higher State bodies. This differentiated legal form, beyond receiving the name "Constitution", is identified with the procedural aggravation and/or State bodies difference in comparison with those of ordinary legislation (Jellinek, 1929, 534-539), that is, by a minimum degree of rigidity or entrenchment, which gives the Constitution its formal outlook and its position of supremacy within the legal system (Kelsen, 2008, 222-224). This makes the formal concept of the Constitution a descriptive -and not normative- concept and, without doubt, this has consequent implications regarding the theoretical issues raised by constitutional amendment. Indeed, for this formal concept of the Constitution there is no legal need to 


\section{B. Alaez Corral}

distinguish between constituent power and constitutional amending power, since only the latter is a legal power with competence to modify an older Constitution or to create a new one, wherein the original constitutional power remains as a mere fact (Carre de Malberg, 1962 , 490-491) or as a power whose legal nature has to be built through a presupposed rule, the Grundnorm, whose sole function is to give abstract validity -regardless of its content- to the positive law Constitution approved ex nihilo by the original constituent power (Kelsen, 2008, 217-219). Therefore, for the formal concept of the Constitution the attribution of the constituent power to the People is contingent and only takes place when the constitutional text has established a democratic constitutional amending power.

\section{Implications of the formal concept of the Constitution for constitutional amendment}

From this formal point of view, constitutional amendment is a theoretical category relevant for the continuity between Constitutions, as it allows the positive law foundation of a constitutional text in another precedent one, whose partial or total modification is produced following the constitutional amendment procedures provided by the former. Constitutional rigidity hence is necessary for the formal differentiation of the Constitution and gives stability to the values of constitutionalism as long as it has positivized them, but does not play any role in the safeguarding of any supra-positive values that condition neither the elaboration nor the amendment of the constitutional text. For the formal concept of the Constitution the distinction between constitutional mutation, constitutional amendment and constitutional breach is decisively relevant, since it allows distinguishing the secundum constitutionem adaptation of the Constitution to social changes -without modifying the constitutional text by way of judicial interpretation or political practice (Böckenförde, 1999, 153)-, from the required formal change of the constitutional text when its openness is no longer capable of embracing interpretative mutations respectful of its literality, as well as from the Constitution's breach as a result of a contra constitutionem mutation or change, a constitutional amendment or new constitution drafting outside the constitutionally established amendment procedure. Accordingly, the so-called “constitutional amendments for disuse" (Albert, 2014, 641) would neither be legally admissible (Orfield, 1942, 81-82). 


\section{Constitutional Amendment and Concept of Constitution}

A formal concept of the Constitution considers the constitutional amending power the only legally true constituent power. Under the formal requirement that it follows the constitutional amending procedure, the established amending power is empowered to make changes into the Constitution or even to change the Constitution by replacing or repealing it, and is only subject to substantial limitations if the positive constitutional text has foreseen them (Carre de Malberg, 1962, 497). A legal differentiation between constituent power and amending power is only relevant if the Constitution provides for two procedures of constitutional change: an ordinary amendment procedure, entrenched in comparison with ordinary legislation but carried out by the same State organs, and an extraordinary amendment procedure, also entrenched but carried out by different State organs considered constituent bodies (Jellinek, 1931, 12-13; Leistner 1932, 20-21).

The possible substantial limitations upon constitutional amending power can be classified under this formal concept of the Constitution as heteronomous, autonomous and absolute. Heteronomous limitations are those coming from a positive law other than the State (Jellinek, 1931, 5). If we put aside the member states constitutions within a Federal State lacking supremacy because of its subordination to the Federal Constitution, today these heteronomous limitations are reduced to the limits derived from International Law or the Law of the European Union. One example of them is represented by art. 193.4 of the Federal Constitution of Switzerland. Heteronomous limits, in principle, do not have absolute but relative character, and could be surpassed by the amending power itself, first by eliminating the limitation and then modifying the matter subject thereof. They could only be conceived as absolutely unamendable if their binding effect is grounded not in the State Constitution, but in International (or European) Law, provided the whole legal system is reduced to unity from a monistic perspective with "primacy of international law", and the State Constitution is considered to derive its validity ultimately from the International Law "principle of effectiveness" (Kelsen 1960, 239-241). Anyway, the legal effectiveness of these heteronomous limitations clashes with obvious problems derived from its vagueness and lack of definition, as well as from its weakened enforcement. On the one hand, there are few constitutional texts somehow accepting this monism with primacy of International Law and placing International Law or European Union Law at least in the hierarchical level as the national Constitution (Aláez Corral, 2017, 19-20). On the other hand, where this monism is not constitutionally accepted, constitutional norms or their amendments violating International or European Law obligations are nonetheless 


\section{B. Alaez Corral}

considered binding within the State, even though they do not modify international obligations (Jellinek, 1931, 6), and even may carry the State's international responsibility if the State does not proceed in accordance with the provisions of international law.

The category of autonomous limitations refers to those limits whose source of production is the State Constitution itself (Leistner 1932, 18). They express a constitutional polymorphism that distinguishes between ordinary constitutional provisions, amendable through the amendment procedure, and extraordinary important constitutional provisions, which are unamendable. These autonomous limitations can appear as the so-called "intangibility clauses" -e.g. art. 79.3 of the German Constitution, art. 89 of the French Constitution or art. 139 of the Italian Constitution-, or as in implied limitations -different from those argued by the material concept of the Constitution- which, derived through a systematic interpretation from other constitutional provisions, include both fundamental contents of the Constitution -the form of State, the fundamental rights and any other fundamental decisions- (Jellinek, 1931, 11-12), and the constitutional amendment procedure itself (Leistner, 1932, 24). However, these autonomous limitations are not considered absolute, but relative, because they could be overcome either by the extraordinary power of amendment -where there are two different powers of amendment of different scope and procedural aggravation, as is the case of arts. 167 and 168 of the Spanish Constitution of 1978- or by the ordinary power of amendment -where there is no more than one constitutional amendment procedure- in a double degree constitutional amendment, first abolishing the limit and then modifying the matter subject to it (Biscaretti di Ruffia, 1948-1949, 122; Vedel 1993, 89-90).

The last and most problematic type of substantial limitations, due to its difficult compatibility with the theoretical premises of the formal concept of the Constitution, is the one referring to the absolute limitations, whose source of production is not a concrete State's organ will, but the very essence of the Law. For the formal concepts that admit them, these absolute limitations are implicitly based on the fact that the Law, including the Constitution, is created by a power inspired by a certain idea of law whose intention is to be effectively imposed as positive law in the sense of a temporarily existing reality (Larenz, 1967, 32). To this idea of law belongs the need to be valid law (Jellinek, 1931, 15-17) and 


\section{Constitutional Amendment and Concept of Constitution}

to be a unified, coherent and functioning legal document (Wright, 1991, 743). These material limitations are derived from the necessary bridge between the ideal validity of the law and its real effectiveness. So, for instance, an apparently valid constitutional amendment, leading to the loss of the Constitution's effectiveness as a result of the impossibility or incomprehensibility of its content, would breach this absolute limitation upon constitutional amendment (Esposito, 1964, 144-145). Other prototypical examples would be the logical prohibition of legally validating a constitutional breach, since it would legally accept the loss of validity of the previous Constitution, in particular of its constitutional amendment rules (Jellinek 1931 14-15; Leistner, 1932, 54), but also the requirement of linguistic comprehensibility of the constitutional amendment, or its physical, moral or political feasibility, since its violation could lead to the loss of efficacy of whole legal system (Jellinek, 1931, 18-22; Esposito, 1964, 144-145), and finally the need to maintain a constitutional amendment procedure as guarantee of the law's adaptation to the social and political changes and therefore of its remaining in force (Jellinek, 1931, 23-24).

\section{Short discussion of the formal concept of the Constitution}

The last category of absolute substantial limitations upon constitutional amendment narrows the formal concept of the Constitution to the material one, even though the absolute amendment limitations of the former do not derive from moral or political values existing outside and above positive law, but from internal functional requirements of law's positivity.

In any case, this type of absolute substantial limitations puts on the table the differences between a kind of static legal positivism rooted in the 19th century German Public Law scholarship and a dynamic legal positivism represented by the Vienna School regarding the understanding of constitutional amendment (Aláez Corral, 2000, 14-56). For the former, any Constitution lacking a specific constitutional amendment procedure is considered an amendable Constitution that can be amended by the same procedure it was originally enacted, in a kind of form parallelism implicit in the will of the constituent. For the latter, on the contrary, all legal norms, including the Constitution, have a claim of temporarily unlimited validity, that is, they are logically unamendable (Verdross 1968, 1545; Merkl, 1968, 1079). If they lose validity after the subsequent approval of a norm it 


\section{B. Alaez Corral}

is because there is a "derogatory clause" (Merkl, 1923, 255) implicit in the constitutional provisions regulating law production, by virtue of which the Constitution provides for the loss of validity of all law derived from it either by virtue of the enactment of a norm of the same weight that replaces it (lex posterior derogat priori), or by enactment of a norm of higher weight with whose content falls into contradiction (lex superior derogat inferiori). This implicit derogatory clause is lacking regarding constitutional norms where the Constitution has not expressly provided for an amendment procedure, but also regarding the provisions on constitutional amendment, whenever these are present, if they have not been codified as self-referring provisions (Merkl, 1923, 178).

This logical unamendability is intended to reinforce the logical supremacy of the Constitution by preventing the same State organ from exercising two hierarchically ordered powers: the legislative and the constitutional amending power. But one thing is that the Constitution's supremacy does not depend on whether a mechanism to modify its provisions has been established, and a very different thing is that the Constitution can only be amended when it expressly provides for an amendment procedure. In other words, the fact that between entrenchment and supremacy there is no correlation does not mean that there is indeed a correlation between constitutional silence and absolute unamendability. Moreover, given that for this formal concept of the Constitution constitutional identity is equivalent to the differentiated constitutional form, the latter is more effectively guaranteed by the principle of legal continuity -understood as constitutional continuity- (Kelsen, 1966, 98-99) than by the logical unamendability of the Constitution.

An additional challenge faced by the formal concept of the Constitution is related to the difficulties to identify the constitutional form, namely in the case of what Pfersmann (2012, 93-94) has called constitutional polymorphism, a growing phenomenon in the context of European integration and human rights globalization, where EU Law or International Human Rights Law in many cases is endowed with constitutional weight (e.g. art. 23.1 German Grundgesetz or art. 50.4 Austrian Federal Constitutional Act). Without a clear constitutional definition of the hierarchical position -in terms of positive law and not only in logical terms- of each of the legal forms, whose elaboration/amendment follows an aggravated procedure in comparison with ordinary legislation, as well as of the legal consequences of the violation of this aggravated procedure -ex ante, ex post review or no 


\section{Constitutional Amendment and Concept of Constitution}

constitutional review at all-, it becomes more difficult to determine what is the legal form we can call a Constitution and what role plays the constitutional amendment in the preservation of its supremacy. The requirement that constitutional amendments must take place expressly (e.g art. 79.1 German Grundgesetz or art. 44.3 Austrian Federal Constitutional Act) -in order to avoid what Löwenstein $(1931,171-172)$ called "constitutional breaks"- does not solve the problem, especially when constitutional polymorphism includes norms produced by different bodies, such as the State Constitution, International Law and European Union Law, and there is no constitutional provision requiring a regulatory consolidation between them.

Finally, constitutional texts are often silent regarding what happens if the rules on constitutional amendment are violated. This relates to the question of whether the judicial review of constitutional amendments is possible or not. For the formal concept of the Constitution this review is possible only if the constitutional text has provided for it -or has allowed its legal provision-, and in a constitutional democracy it should be in the hands of the judiciary (Kelsen, 1968, 1533), but it is not inherent to the Constitution's concept and it is even possible that Courts refuse to have this review power when it is not expressly provided for (Judgment of the French Constitutional Council DC2003-469 and Judgment of the Supreme Court of the United States of 1922, Leser v. Garnett, 258 U.S. 130). But what happens if nothing has been stated in the constitutional document? In such a case, from the point of view of a formal concept of the Constitution this judicial power to review constitutional amendments could only be affirmed if it can be interpretatively deduced from the provisions offered by the constitutional text, and not from any supra-positive values (Pfersmann, 2012, 101-103). The formal concept of the Constitution does not give a clear answer to the question of whether constitutional amendment rules are only logically higher constitutional law -as far as they regulate constitutional law production- or, on the contrary, if they are also higher constitutional positive law as far as their violation may have invalidating/derogatory effects. In this sense, constitutional amendment rules would be only logically higher constitutional law if no ex post constitutional amendments judicial review is foreseen. Conversely, the constitutional amendment rules will become a higher constitutional positive law if there is an ex post judicial review of constitutional amendments and it has invalidating/derogatory effects. But then the problem that arises is that this constitutional polymorphism challenges the purely formal definition of the 


\section{B. Alaez Corral}

Constitution, since there would be formally superior and formally inferior norms within the constitutional text; or, in other words, some would be the "true" formal Constitution and others should simply be assimilated to aggravated legislation regardless of its legal naming as "Constitution".

\section{An alternative approach: constitutional amendment under a formal-functional concept of the Constitution}

1. Constitutional text supremacy as a means for the functional differentiation of the law

The choice between one concept of the Constitution or the other presents several methodological and epistemological implications that cannot be discussed here in detail. Let us just say that, in our understanding, the object of legal science is to describe the objective and systematic meaning of norms belonging to positive law (Kelsen, 2008, 7071). The justification for this understanding of legal science relies on the fact that it allows a more rational knowledge of the legal system, and that in democratic legal systems this methodology also helps to protect democracy as a procedure, as a form of government settled and ruled by the law (Kelsen, 1955, 3-5).

Considering the theoretical difficulties, discussed earlier, that the material and the formal Constitution concepts pose regarding constitutional amendment, either due to their dependence on a supra-positive law or due to their dependence on a procedural formalization not always generating a constitutional law supremacy, we will next give an account of an alternative approach -certainly related to the formal concept of the Constitution- which seems more adequate to the current tendency of legal systems to formally and functionally differentiate themselves from the rest of social communication subsystems and therefore to our understanding of the aim of legal science. This is a formalfunctional concept of the Constitution. It is formal, on the one side, because the Constitution's definition takes into account a differentiated positive law form adopted by the law we call a "Constitution", but it is also functional because it inextricably associates this constitutional form with a supremacy position -in terms of positive law and not merely in terms of logic- that the Constitution enjoys precisely due to the intrinsic function it plays for the legal system. Therefore, it is not possible to define the constitutional form -nor its 


\section{Constitutional Amendment and Concept of Constitution}

associated supremacy position- only on the basis of the formal outlook of the constitutional norm, overlooking its function as a structural consequence of the differentiation of the legal system.

This formal-functional approach understands the law as a social subsystem whose existence (validity) depends on its progressive functional differentiation with respect to its environment (Economy, Politics, Moral...). Its specific function is the counterfactual stabilization of expectations through the regulation of (ultimately physical) coercion. In this context the democratic Constitution represents an evolutionary decisive step for this functional differentiation of the law as it is the legal communication (norm) that best contributes to the realization of the positivity and self-reference of the law (Bastida Freijedo, 1998, 389), in particular thanks to the guarantee of fundamental rights as instruments through which the legal system opens itself cognitively to its environment while maintaining its structural self-reference, that is, its functional differentiation (Luhmann, 1999, 23-25). Thus, the Constitution, as an element of an autopoietic legal system, can only be explained self-referentially, that is, in accordance with the formal rules of communication in which the legal system consists. This does not mean that the Constitution lacks a political substance, since social systems, including law, are not isolated elements but need a certain degree of cognitive openness towards their environment, from which they take expectations to maintain its positivity (Luhmann 1993, 77). But once a political expectation is self-referentially positivized and becomes part of the Constitution, it becomes also an internal element of the legal system and is governed by the formal rules of production and derogation the law itself has provided for (Luhmann, 1993, 38).

Therefore, the functional differentiation of the law requires positivity for channeling the necessary cognitive openness of the legal system, that is, possibilities of change to adapt to the environment and remain differentiated, but it also requires selfreference in order to keep its necessary formal (operational) closure, that is, binding legal procedures for changing the law's contents. Certainly, the Constitution represents, due to its position of legal supremacy, a limitation upon the law's positivity, by limiting the cognitive and norm production capacity of the infra-constitutional levels, but at the same time, through its constitutional amendment clauses, it safeguards the self-reference of the system since it does not completely close the cognitive capacity of the system to internalize 


\section{B. Alaez Corral}

new expectations coming from the environment, and only requires to follow the amendment procedure for changing the constitutional contents.

\section{Implications of functionalizing the constitutional form for the constitutional amendment}

The theoretical framework described above has certainly implications for giving a differentiated response to the issues raised by constitutional amendment, as long as constitutional amendment is the instrument the legal system has at highest level to adapt to the changes in its social environment without losing differentiation. Establishing a constitutional amendment procedure grants legitimacy, through legality, to the make changes in or of the highest legal program of the operating system of a political. And it does so by legalizing the constituent power as a constitutional amendment power, that is, as a constituent-constituted power (Aláez Corral, 2000, 147). Hence, from a formalfunctional perspective, only the formal constitutional amendment is functionally adequate for the preservation of the differentiation of the legal system, whereas neither the constitutional mutation contra constitutionem, nor the exercise of the original constituent power outside the constitutionally provided procedure -no matter how peacefully it may have been or how to much citizen's direct participation it has involved-, can be claimed to be adequate for that purpose.

Constitutional rigidity fulfills for this formal-functional concept a different function than it did for the formal one. On the one hand, it facilitates the differentiation of the legal system, by articulating a self-referring law's changing procedure that gives formal continuity to the legal system, nonetheless allowing its permanent cognitive openness to the constitutionalizing of new expectations formed in the social environment. On the other hand, it also expresses -according to the degree of constitutional entrenchment established (Albert, 2009, 670)-, the level of counterfactual stabilization that the law grants to the already constitutionalized expectations, in particular to those expressed by the values of constitutional democracy, and that depends on the political culture existing in that social environment (Gingsburg/Melton, 2015, 686). Unlike the formal concept, rigidity is no longer useful to identify the Constitution, because the latter is identified exclusively by its derogatory position of supremacy, regardless of the degree of entrenchment established 


\section{Constitutional Amendment and Concept of Constitution}

according to its assessment of the environment's complexity and the risk of attempts to normativize illiberal expectations by illegal means; that is, outside the constitutional amendment procedure.

Indeed, the Constitution's supremacy requires its formal identification, but this can only be done if the constitutional form and its amendments are expressly labeled as such, and if constitutional polymorphism is ordered in terms of derogatory hierarchy. For this reason, no extra ordinem constitutional changes can be legally accepted, since they represent violations of the constitutional form that undermine the self-reference of the law and its functional differentiation, so the Constitution is not supposed to implicitly allow them. To preserve democracy (self-government) requires to preserve the derogatory supremacy of a democratic Constitution on top of a legal system endowed with full positivity and self-reference, and this is linked to formal constitutional continuity. This continuity is not based on the Constitution's correspondence with any meta-positive system of political values presupposed in the People's will, nor in any logical legal hypothesis, but on the existence of the legal system as a differentiated social system. For the purpose of this differentiation, it is better that any constitutional revolution -in the sense of a change of fundamental political values- takes place by legal means, rather than outside the law. It is essential that the Constitution itself provides for democratic constitutional amendment procedures (self-reference) without absolute substantial limitations (positivity). This would allow new generations to accept and therefore grant legitimacy to the constitutional framework they are subject to, as long as they can make changes in it or replace it through a democratic procedure.

Although the above-mentioned positivity of the legal system may have led constitutional texts all over the world, for many different political, historical and cultural reasons (Hein, 2019, 196), to a generalized inclusion therein of amendment prohibitions affecting certain constitutional contents (Hein, 2018), these intangibility clauses are dysfunctional for the differentiation of the legal system because they imply its cognitive closure. Therefore, unless its absolute character is expressly provided -or can interpretively be deduced from the whole of the constitutional text- these clauses must be considered relative, and they could be surpassed in a two-degree amendment procedure: first by eliminating the intangibility clause, and secondly by modifying the constitutional contents 


\section{B. Alaez Corral}

already freed from intangibility. The logical impossibility that the beneficiary of a constitutionally reserved (and limited) amending power may be allowed to dispose of this delegation has been opposed to this double degree amendment (Moreso, 1991, 205-208). However, this reasoning presupposes a derogatory hierarchy between the constitutional norms attributing the amending power -constitutional amendment clauses- and the other constitutional norms as well as the constitutional norms resulting from the exercise of that amending power -the new modified constitutional amending clause-, a hierarchy which does not usually exist, or at least is not usually expressly established by the Constitution (Aláez Corral, 2000, 216-220).

Besides this, it must be noted that, despite the linkage of these substantive limitations upon the constitutional amending power with a model of militant democracy proposed by Löwenstein (1937, 424), its enforcement practice by European Constitutional/Supreme Courts in the last 80 years highlights the fact that they have hardly served for the protection of democracy as positivized by the constitutional texts: the Constitutional/Supreme Courts, either on lack of competence grounds or due to a narrow interpretation of the abstract unamendable values, tend not to invalidate the constitutional amendments that contravene intangibility clauses; and, moreover, in the majority of the few cases in which they have invalidated the amendments this had the opposite effect of dismantling the values of the constitutional democracy (Hein, 2020, 29-30). This does not mean that it is not possible to assess whether a constitutional amendment opposes constitutional democracy, but in case it has happened we will face a constitutional violation, by not respecting the formal and/or substantive limitations upon constitutional amendment, and this illegal enactment of a new (completely or altered) Constitution can only be evaluated from the perspective of political theory, not of legal science.

This last idea connects, finally, with the issue of the judicial review of constitutional amendments. Certainly, nothing prevents a constitutional text from granting the Courts the power to review the conformity of the constitutional amendments with the constitutional amendment rules, explicitly or interpretively deduced from the positive constitutional text, as, for instance, does the Supreme Court of Canada in Reference re Supreme Court Act, ss. 5 and 6 (2014 SCC 21). Nonetheless, from the point of view of preserving the Constitution's functionality for the differentiation of the legal system, such 


\section{Constitutional Amendment and Concept of Constitution}

review should be established as an $e x$ ante review of the procedural acts leading to a constitutional amendment (e.g. art. 82.2 Constitution of Chile and article 146a) Constitution of Romania, confirmed by the Judgment of the Constitutional Court of Romania 686/2003 of September 30) and not as an ex post review of the approved constitutional amendment (e.g. art. 167.4.d) Constitution from South Africa). This seems to us the most adequate approach to the Constitution's function for the legal system, and not the denial of such power of review in case of silence on the part of the constitutional text (Götzler, 2008, 12-13). It must be taken into account that constitutional amendment represents the legalization of social expectations previously outside and even contrary to the legal system; in other words, it represents a bridge between politics and the law, and that requires keeping constitutional amendment in the field of politics away from the legal field of the Courts (Tribe, 1983, 442-443), as an ultimate way to safeguard the democratic legitimacy of a government founded on the consent of the governed (Vile, 1995, 198).

Therefore, from the point of view of a formal-functional concept of the Constitution, talking about unconstitutional constitutional norms, as Bachof $(1979,17)$ did, can only be explained either by deconstitutionalizing the constitutional text for the benefit of a supra-positive material Constitution or by degrading the hierarchical supremacy position of the amendable part of the constitutional text to the weight of supra-legality, but no longer to constitutional weight, which would only have the rules on constitutional amendment and the unamendable constitutional provisions. On the contrary, if the norms resulting from a constitutional amendment are conceived as constitutional norms of the same hierarchical weight as the constitutional norms they amend and the constitutional amendment rules -that would also be amendable-, it would not be functional to understand that the Constitution has enabled a constituted power -the judiciary- review, and eventually invalidate approved constitutional provisions, which for instance could foresee the abolition of such derogatory effects either of the constitutional amendment rules or even of the whole Constitution (Aláez Corral, 2000, 391). In addition, this formal-functional approach to judicial review of constitutional amendments would allow to reconcile, in democratic Constitutions, the legally binding nature of constitutional amendment rules -as part of the Constitution- with the counter-majoritarian (and partially anti-democratic) effects of judicial review of constitutional amendments. It is not that Courts are not allowed to review the direct will of the sovereign People (as the Irish Supreme Court at Riordan v an Taoiseach (2001) 4 IR 463 or the French Constitutional Council at DC62-20 have 
B. Alaez Corral

argued). Sovereignty may politically be vested in the People, but legally speaking it is a feature of legal system as a whole, and it is represented by the Constitution as its supreme law. If the acts of the constitutional amendment procedure are reviewed ex ante in the light of the constitutional amendment rules, still constituted acts will be reviewed under the higher law of the Constitution; whereas if the review takes place ex post, over an already approved constitutional amendment, a constituted counter-majority power (the Courts) would be allowed to invalidate the will of the legalized constituent power, which represents a higher (constitutional) law for the former and enjoys majoritarian democratic legitimacy.

Only keeping this in mind could perhaps democracy be protected, from the inside of the legal system, through the institution of constitutional amendment.

\section{LIST OF REFERENCES}

Ackermann, B.,

- (1991) We the People: Foundations, The Belknap Press of Harvard University Press, Cambridge, Massachussets

- (1997) The Rise of World Constitutionalism, Virginia Law Review, Vol. 83, pp. 771-797 Aláez Corral, B.,

- (2000) Los límites materiales a la amendmenta de la Constitución española de 1978, CEPC, Madrid

- (2017) Legal Globalization from the Perspective of Spanish Constitutional Law, Annuario di Diritto Comparato e di Studi Legislativi, pp. 5-46

Albert, R.,

- (2009) Constitutional Handcuffs, Arizona State Law Journal, Vol. 42, pp. 663-715

- (2014) Constitutional Amendment by Constitutional Desuetude, American Journal of Comparative Law, Vol. 62, pp. 641-686

- (2015) The Theory and Doctrine of Unconstitutional Constitutional Amendment in Canada, Queen's Law Journal, Vol. 41, pp. 143-176 


\section{Constitutional Amendment and Concept of Constitution}

Austin, J., (1970) The Province of Jurisprudence Determined, Lennox Hill, New York, 1970 (reprint of the second edition 1861)

Bachof, O., (1979) Verfassungswidrige Verfassungsnormen? (1951), in «Wege zum Rechtstaat. Ausgewählte Studien zum öffentlichen Recht», Atheneum, Königstein

Bastida Freijedo, F.J., (1998) La soberanía borrosa: La democracia, Fundamentos. Cuadernos monográficos de teoría del estado, derecho público e historia constitucional, Vol. 1, pp. 381-460

Bernal Pulido, C., (2018) Prescindamos del poder constituyente en la creación constitucional. Los límites conceptuales del poder para reemplazar o amendmentar una constitución (Constitution-making (without) constituent power: on the conceptual boundaries of the power to replace or amend the Constitution), Anuario Iberoamericano de Justicia Constitucional, Vol. 22, pp. 59-99

Biscaretti di Ruffia, P., (1948-1949) Sui limiti della revisione costituzionale, Annali del Seminario giuridico della Universita di Catania, № 3, pp. 122-172

Böckenförde, E-W.,

- (1999) Anmerkungen zu. Begriff Verfassungswandel, in Staat, Nation, Europa, Suhrkamp, Frankfurt a.M.,

- (1991) Die Methoden der Verfassungsinterpretation. Bestandaufnahme und Kritik, in

Staat, Verfassung, Demokratie. Studien zur Verfassungstheorie und zum Verfassungsrechts, Suhrkamp, Frankfurt a. M.

- (2017) The Constituent Power of the People. A Liminal Concept of Constitutional Law, in Künkler/Stein (Edits.), Constitutional and Political Theory. Selected Writings, Oxford University Press, Oxford

Carre de Malberg, R., (1962) Contribution à la théorie générale de l'État (reimpresión de la edición de 1920-1922), Tomo II, CNRS, Paris

Corwin, E., (1929) The "Higher Law" Background of American Constitutional Law, Harvard Law Review, Vol. 42, pp. 365-409

Ehmke, H., (1953) Grenzen der Verfassungsänderung, Duncker \& Humblot, Berlin Esposito, C., (1964) La validità delle leggi, Giuffrè, Milano, (reprint of the edition 1934) 
B. Alaez Corral

Gingsburg, T./Melton, J., (2015) Does the Constitutional Aamendment Rrule Matter at All? Amendment Cultures and the Challenges of Measuring Aamendment Difficulty, International Journal of Constitutional Law (I-CON), Vol. 13, pp. 686-713

Götzler, K., (2008) Judicial Review of Constitutional Amendments: A Comparative Study, Ekin Press, Bursa

Griffin, S. M., (2007) Constituent Power and Constitutional Change in American Constitutionalism, in Martin Loughlin/Neil Walker (Edits.) The Paradox of Constitutionalism Constituent Power and Constitutional Form, Oxford University Press, Oxford

Grimm, D., (1995) Does Europe Need a Constitution?, European Law Journal, N. ${ }^{\circ}$ 1, pp. 282-302

Hauriou, M., (1923) Precis de Droit Constitutionnel, Recueil Sirey, Paris

Hein, M.,

- (2018) The Constitutional Entrenchment Clauses Dataset, Göttingen, University of Göttingen, available at: http:// data. michaelhein.de (accessed January $15^{\text {th }} 2020$ )

- (2019) Impeding Constitutional Amendments: Why Are Entrenchment Clauses Codified in Contemporary Constitutions?, Acta Politica, Vol. 54, pp. 1-29

- (2020) Do Constitutional Entrenchment Clauses Matter? Constitutional Review of Constitutional Amendments in Europe, International Journal of Constitutional Law, Vol. 18 ,

pp.

$1-35$

(https://www.academia.edu/37664072/Do_Constitutional_Entrenchment_Clauses_Matter

_Constitutional_Review_of_Constitutional_Amendments_in_Europe) (accessed January $\left.15^{\text {th }} 2020\right)$

Jellinek, G., (1929) Allgemeine Staatslehre, Julius Springer, Berlin, (reprint of the third edition 1914)

Jellinek, W., (1931) Grenzen der Verfassungsgesetzgebung, Julius Springer, Berlín

Jeselsohn, S., (1929) Begriff, Arten und Grenzen der Verfassungsänderung nach Reichsrecht, Carl Winters Universitätsbuchhandlung, Heidelberg 


\section{Constitutional Amendment and Concept of Constitution}

Kay, R. S., (2011), Constituent Authority, The American Journal of Comparative Law, Vol. 59, pp. 715-762.

Kelsen, H.,

- (1955) Foundations of democracy, Ethics, Vol. 66, No. 1, Part 2, pp. 1-101

- (1968) Wer soll der Hüter der Verfassung sein (1931), in Klecatsky/Marcic/Schambeck (Edit.), Die wiener rechtstheoretische Schule, Europa Verlag, Vienna

- (1949) General Theory of Law and State, Harvard University Press, Harvard

- (1960) Das Problem der Souveränität und die Theorie des Völkerrechts (reprint of the second edition 1928), Scientia, Aalen

- (2008) The pure theory of law, The Law Book Exchange, New Jersey (reprint of the second edition 1960)

Larenz, K., (1967) Das Problem der Rechstgeltung, Wissenschaftliche Buchgesellschaft, Darmstadt (reprint of the second edition 1929)

Leistner, J.F., (1932) Grenzen der Verfassungsgesetzgebung, Hilz Druck, Nürnberg

Liet-Veux, G., (1943) La “fraude a la Constitution". Essai d'un analyse juridique des revolutios communautaires recentes: Italie, Allemange, France, Revue du droit public et de la science politique en France et à l'étranger, Vol. LIX, No. 2, pp. 116-150

Löwenstein, K.,

- (1968) Erscheinungsformen der Verfassungsänderung, Scientia, Aalen, (reprint of the edition 1931)

- (1937) Militant Democracy and Fundamental Rights I, American Political Science Review, Vol. 31, No 3, pp. 417-432

Luhmann, N.,

- (1993) Das Recht der Gesellschaft, Suhrkamp, Frankfurt a.M.

- (1995) La Constitution comme acquis evolutionnaire, Droits, $\mathrm{N}^{\circ}$ 22, pp. 103-125

- (1999) Grundrechte als Institution, Duncker und Humblot, Berlín 1999 (reprint of the edition 1965) 
B. Alaez Corral

Merkl, A.,

- (1923) Die Lehre von der Rechtskraft. Entwickelt aus dem Rechtsbegriff, Leipzig

- (1968) Die Unveränderlichkeit von Gesetzen. Ein normologisches Prinzip (1917), in Klecatsky/Marcic/Schambeck (Edit.), Die wiener rechtstheoretische Schule, Europa Verlag, Vienna

Moreso, J.J., (1991) Disposiciones de reforma constitucional, Doxa, $\mathrm{n}^{\circ}$. 10, pp. 201-222

Mortati, C., (1940) La Costituzione in senso materiale, Giuffré, Milano

Nef, H., (1942) Materielle Schranken der Verfassungsrevision, Zeitschrift für Schweizerisches Recht, Vol. 61, pp. 108-138

Offe, C., (1998) "Homogeneity" and Constitutional Democracy: Coping with Identity Conflicts through Group Rights, The Journal of Political Philosophy, Vol. 6, № 2, pp. 113141

Orfield, L.B., (1942) The Amendment of the Federal Constitution, University of Michigan Press, Ann-Arbor

Pfersmann, O., (2012) Unconstitutional Constitutional Amendments: A Normativist Approach, Zeitschrift für öffentliches Recht, Vol. 67, pp. 81-113

Roznai, Y., (2017) Unconstitutional Constitutional Amendments.The Limits of Amendment Powers, Oxford University Press, Oxford

Schmitt, C.,

- (1929) Der Hüter der Verfassung, Archiv des öffentlichen Rechts, Vol. 55, № 2, pp. 161237

- (1989) Verfassungslehre, Duncker und Humblot, Berlin (reprint of the first edition 1928)

Schwarzberg, M., (2007) Democracy and Legal Change, Cambridge University Press, Massachussets

Smend, R., (1968) Verfassung und Verfassungsrecht (1928), in Staatsrechtlichen Abhandlungen, Duncker \& Humblot, Berlin 1968

Tribe, L., (1983) A Constitution We Are Amending: In Defense of a Restrained Judicial Role, Harvard Law Review, Vol. 97, pp. 433-445 


\section{Constitutional Amendment and Concept of Constitution}

Vedel, G., (1993) Souverainete et supraconstitutionnalite, Pouvoirs, Nº 67, pp. 79-97

Verdross, A., (1968) Zum Problem der Rechtsunterworfenheit des Gesetzgebers (1916), in Klecatsky/Marcic/Schambeck (Edit.), Die wiener rechtstheoretische Schule, Europa Verlag, Vienna

Vile, J.R., (1995) The Case Against the Implicit Limits on the Constitutional Amending Process, in Sanford Levinson (Edit.), Responding to Imperfection. The Theory and Practice of Constitutional Amendment, Princeton University Press, Princeton

Wright, R. G., (1991) Could a Constitutional Amendment Be Unconstitutional?, Loyola University Chicago Law Journal, Vol. 22, pp. 741-764. 